\title{
Teacher Management: Emerging Issues in Kenya
}

\author{
Dorothy Owuor Jonyo, PhD \\ Moi University, Kenya \\ Bonn Odera Jonyo, PhD Candidate \\ Business Administration in Leadership \\ at United States International University - Africa
}

doi: 10.19044/ejes.v4no1a18 URL:http://dx.doi.org/10.19044/ejes.v4no1a18

\begin{abstract}
This is a conceptual paper which reviewed teacher management in Kenya with a particular focus on the emerging issues. Organizations in all sectors are striving to succeed despite the many challenges they face including issues of globalization, rapid changes, especially changes in technology, leadership dynamics and increased competition among others. Organizations' perspective today in the third world are striving to maximize on their major resources to develop and grow their entities by use of teachers acting as their strategic managers in provision of quality of education and teacher management. It reviewed what TSC Act as enacted under the 2010 Kenyan Constitution and its subsequent transformation to an independent commission with an enhanced mandate stipulates. It has delved in the synopsis of emerging issues such as teacher shortage, provision of quality education, professionalizing the teaching service, promotion of teachers, teachers conduct and performance, litigation, information, communication and technology integration, management of HIV and AIDS, industrial unrest, and deployment of effective teachers leadership positions. In summary more budgetary allocation is required to address teacher deficits, employ more counsellors, enforce TSC Act provision and involve all the stakeholders to make the profession more attractive and enhance retention of well trained, qualified and experienced teachers. Transformational leadership model is a key component in managing teachers' affairs.
\end{abstract}

Keywords: Deployment, litigation, discipline, morale.

\section{Introduction}

Teacher management in Kenya is a mandate executed by the Teachers Service Commission Kenya (TSC). The most important way to succeed is to use various determinants which may favour implementation of 
teacher management strategies that are critical for yielding desired results. Organizational determinants are so important and can lead to success or failure of any organization. On the other hand, teacher management strategy is an important component both at national and regional levels to implement. Teacher management strategy implementation is the last phase and particularly determines what an organization will be in future (Pearce and Robinson, 2013). The Teachers Service Commission is established under the constitution to perform all teacher management functions following the enactment of Kenya Constitution 2010 under Article 237 and the enactment of TSC Act no 20 of 2012 (TSC Annual Report, 2012-2013). Under the new constitution 2010, TSC was transformed to a constitutional Commission with expanded mandate. The Directorate of Teacher Management is the professional arm of the Commission and is mandated to carry out the following core functions:

- To register trained teachers.

- To recruit and employ registered teachers.

- To assign teachers employed by the commission for service in any public school or institution.

- To promote and transfer teachers.

- To review the standard of education and training of persons entering the teaching service.

- To review the demand for and supply of teachers.

- To advise the national government on matters relating to the teaching profession.

- To establish and maintain a Teachers Service adequate to the needs of public schools and tertiary institutions in Kenya.

- To publish and compile a code of Regulations which shall apply to all registered teachers and may time to time modify or amend it in such manner as it deems fit. (TSC Act, 2012).

Organizational leadership is the process and practice by key executives of guiding and steering people in an organization towards a vision over time and developing that organization's future leadership. Due to intense competition, volatile and changing management environment coupled with need for effectiveness and survival, good leadership is necessary aimed at improving the standards (Kotter, 1990). Good leadership ensures the ability to anticipate, envision and maintains flexibility to empower others to create strategic change (Hanson, Hitt, Ireland, \& Hoskisson, 2013). Leadership which transforms a vision into reality and motivates people to transcend their personal interest for the good of the group or the organization. 
This review is informed by transformational leadership theory (Kotter, 1990) where leaders use charisma and related qualities to inspire extraordinary efforts. Transformational leadership is change and performance oriented leadership. Effective transformational leadership results in performances that exceed organizational expectations (performance beyond expectation). TSC should use the tenets of transformational leadership in their management of the teachers. This will occur when the leaders: When leaders make followers aware of the importance of their jobs to the organization and how necessary it is for them to perform those jobs well, possess exceptional cognitive skills, believe in people and show sensitivity to their needs, are flexible and open to learning from experience, empowers followers to do what is best for the organization and a strong role model with high values. Tichy \& Ulrich, (1984), on the other hand categorizes major roles of transformational leadership to include: Creation of a vision, mobilization of commitment to the vision and institutionalization of the change throughout the organization.

\subsection{LITERATURE REVIEW EMERGING ISSUES TEACHER SHORTAGE}

Teachers constitute the core of the education system and their importance in students/pupils performance has been widely confirmed by many studies (Rivkin, Stephen, Ertik \& John, 2000). In recent years, an increasing number of studies have expressed concern about current and prospective teacher shortages in many countries. According to Santiago (2002), severe shortages currently exist, and there is a gap between demand and supply of teachers needed to ensure effective teaching in many countries.

Teacher deficit is therefore a major concern to educational authorities taking cognizance of the teacher pupil/student ratio and should be addressed continuously by policy makers. Qualified teachers in both the developed and developing world are becoming the hardest segment of the teaching profession to attract and retain and are the most expensive to educate (World Bank, 2006). In Kenya, weaknesses in human resource planning has affected training and deployment of teachers and thus distorted their distribution and utilization. Consequently, there exists an unbalanced distribution of teachers, teacher shortages, teacher surplus and utilization of teachers (MoEST,2005b) 'There is acute shortage of teachers as students increased due to Free Primary/Free Secondary Education and opening of new schools which the commission had not anticipated. Although the commission has over the years tried to bridge the gaps in teacher establishment across the country, there is still a shortage of over 85,000 teachers (TSC Annual Report, 2014-2015). The determination of staffing requirements is effected in many ways. Some of these norms include curriculum based establishment 
(CBE) used in Post-primary institutions, Pupil: Teacher ratio (PTR) used in primary schools, subject cluster, number of teachers per class and class and class sizes (Akala \& Maithya, 2014).

Globally, the recruitment and retention of highly qualified teachers remains challenging with particularly reference to Sub Saharan Africa, Asia and Latin America. It was estimated that between 2010 and 2015, 6-8 million teachers need to be recruited to ensure quality primary education for all children globally (UNESCO, 2012). In addition, research has shown that academically talented college students are less likely to become teachers and effective teachers in subject areas of shortage are more likely to leave the profession (Hoxby \& Leigh, 2004).

In Kenya, teachers' recruitment was done through supply driven process. It was until 1998 when the government of Kenya froze teacher recruitment as a cost cutting measure as a response to structural adjustment programmes by the International Monetary Fund particularly to developing countries. This led to the adoption of demand driven policy on teacher recruitment in 2001 (TSC, 2002). Under demand driven recruitment policy, the government has been employing limited number of teachers both at primary and post primary institutions annually. However, this does not cater for the actual shortfall. The TSC Annual report 2014-2015 puts the total figure of teacher shortage at 85,000 nationally. Teachers play a significant role in ensuring quality instruction and education in schools. They manage and provide leadership to schools, develop and implement curricula. For these services to be effectively accomplished, teachers must be adequately recruited and deployed to schools. Sessional paper No 1 of 2005 a policy framework for Education, Training and Research in the $21^{\text {st }}$ Century and the Kenya Education Sector Support Programme (KESSP) (Republic of Kenya, 2005), have identified teachers as one of the most important inputs to the education system. The efficient management and utilization of this resource, therefore, remains critical to the quality of the learning outcomes. This shortage is likely to increase with the change of government policy to recruit 5,000 teachers annually as provided by the Medium Term Plan II (MTP II). Consequently, in view of the current teacher shortage and the employment trend, it is projected that by 2016/2017, which is the end of MTP II, more than 94,907 additional teachers will be required in primary and post primary institutions (TSC, 2014-2015). The government should therefore prioritize investing by expanding the budget provision in its budgeting cycle to urgently address this phenomenon.

In order to mitigate teacher shortage the government through the Teachers Service Commission has been carrying out teacher recruitment and replacing those who leave service through natural attrition every year. Recruitment of teachers has been decentralized to TSC County offices for 
primary schools and Board of Management (BOMs) for post primary Institutions. The number of teachers under employment by the end of 2014/2015 period was 249,060 against an enrolment of 13 million learners in both public primary and post primary Institutions. The high rate of teacher rate of teacher attrition, calls not only for quick replacement but also an in depth analysis to determine and predict its effect on demand in order to safeguard against shortages.

A clear teacher demand framework will be necessary not only to rationalize teacher utilization but also to guide in meeting the targets for SDGs in education and Kenya's Vision 2030. The vision for the education sector for 2030 is 'to have globally competitive quality education, training and research for sustainable development”. This vision can only be achieved by focusing on the key strategic areas, namely access, quality, science, technology and innovation have been identified for support based on their impacts on the economic, social and political pillars (GOK, 2007).

Table 1.1 Recruitment of Teachers (2014/2015)

\begin{tabular}{|l|l|l|l|}
\hline $\begin{array}{l}\text { Number of teachers } \\
\text { recruited }\end{array}$ & Primary & Post Primary & Totals \\
\hline $\begin{array}{l}\text { No. of additional } \\
\text { teachers }\end{array}$ & 2,479 & 2,521 & 5,000 \\
\hline $\begin{array}{l}\text { No of replacement } \\
\text { teachers }\end{array}$ & 7,141 & 2,552 & 9,663 \\
\hline Totals & 9,620 & 5,043 & 14,663 \\
\hline
\end{tabular}

Source: Teacher Management Directorate

There was a significant increase in the number of replacements in 2012/2013 from 2,091 to 8,392 in 2013/2014 due to the retirement of teachers who had benefitted from extension of retirement age from 55 to 60 years as from 2008.

Table 1.2: Trends in teacher recruitment in the last three years.

\begin{tabular}{|l|l|l|}
\hline YEAR & Additional teachers & Replacement teachers \\
\hline $\mathbf{2 0 1 2} / \mathbf{2 0 1 3}$ & 10,000 & 2,091 \\
\hline $\mathbf{2 0 1 3} / \mathbf{2 0 1 4}$ & 5,000 & 8,392 \\
\hline $\mathbf{2 0 1 4} / \mathbf{2 0 1 5}$ & 5,000 & 9,663 \\
\hline TOTAL & $\mathbf{2 0 , 0 0 0}$ & $\mathbf{2 0 , 1 4 6}$ \\
\hline
\end{tabular}

Source: Teacher Management Directorate

Although the Commission has over the years made a deliberate effort to bridge the gaps in teacher establishment across the country, there is still a deficit in excess of 85,000 teachers. This is occasioned by increasing enrolment in primary and post primary institutions, expansion of the existing schools and registration of new ones. This situation has resulted in high Pupil Teacher ratio which comprises the quality of education. To bridge the shortage, there is need to recruit 20,000 teachers annually for the next five 
years to adequately address this deficit. This calls for additional funding (TSC Annual report, 2014/2015).

Perhaps an attempt to answer the following questions could give a deeper insight in the teacher shortage and recruitment as posed by Digolo (2013).

- Why are trained and qualified Primary and Secondary teachers not recruited, employed and posted to schools which are experiencing teacher lacks dating back to more than five years?

- Why is there lack of equitable distribution of teachers across the country as per the government policy and the mandate of the Teachers Service Commission?

- Why are their untrained teachers teaching in the Kenyan Primary, Secondary and tertiary classrooms while there are qualified professionals who are still unemployed?

- Why are some graduate teachers from colleges and universities get employed immediately they leave training institutions while others stay for years (5 years or more) before they can be absorbed?

- Why do some graduates get posted to Counties/Sub-Counties in which they do not reside while others are denied citing residence in those places as a criterion?

\section{PROVISION OF QUALITY EDUCATION}

It is often asserted that children's future, and with it the development of the Nation State, depend, to a large extent. On the education system and the skill and dedication of its teachers. Perraton (2005), reminds us that good education demands good teachers and yet and yet in many countries (particularly the developing countries) teachers remain poorly educated, poorly paid and all too often poorly regarded. As moves for greater accountability and quality delivery gain momentum in the public and private sectors, attempts to assess the performance of teachers in a number of different countries have been made. Kenyan teachers have not been exempt from these pressures. Traditionally, Kenya and other developing countries, unsystematic appraisal has long flourished (covertly and unfairly) based on impulse, prejudice and incorrect or inadequate data (Wanzare, 2002).

Within the framework of imposed and intentional changes that have taken place in Kenya's educational system, formalized procedures for the appraisal of teachers' performance are viewed by educators as logical and essential for accountability, quality improvement and best practice. These views shared with Hattie and Clinton (2008) who argue that "the major advantage of assessing teachers is the demonstration that the profession can identify, value and reward the very best ". International research reveals that appropriate appraisal schemes have the potential of improving 
professionalization of teaching, the effective management of schools, the quality of education provided for the students, the professional development of teachers as well as satisfying legitimate demands for accountability (Odhiambo, 2005).

In executing its expanded mandate, the TSC has developed a roadmap to achieve its reform agenda. Top on the list is provision of quality education. This agenda is embedded in the new TSC vision and mission statements, that is;

Vision: To be a transformative teaching service for quality education.

Mission: To professionalize teaching service for quality education and development.

In order to achieve this objective and in line with the government policy, the commission has adopted a Result Based Management (RBM) approach that focuses on performance, efficiency, effectiveness and accountability for results. Performance management (PM) is a goal oriented process directed toward ensuring that organizational processes are in place to maximize the productivity of employees, teams, and ultimately, the organization coupled with strategic leadership with the aim of transforming the service. It is a major player in accompanying organizational strategy in that it involves measuring and improving the value of the work force. Performance Management includes, incentive goals and the corresponding incentive values so that the relationship can be clearly understood and communicated. There is a close relationship between incentives and performance (Houghton, 2010).

The Performance contracting and Teacher Performance Appraisal and Development instruments will be critical in creating a performance oriented culture, measuring and evaluating performance and linking reward to measurable achievements. The TSC Code of Regulation for teachers (2015) Part IV (52) says that, the Commission shall develop an open performance appraisal system for teachers in its employment to strengthen supervision and to continuously monitor the performance of teachers in curriculum implementation at the institutional level. The commission therefore has a mandate to facilitate Teacher Professional Development (TPD) for teachers as provided for by TSC Act. Further, section 35(2) and (b) of the Act and the Government Policy Framework Session Paper No.14 of 2012 state that all teachers are required to undertake professional development courses as prescribed from time to time.

The performance appraisal system was rolled out to all schools in January/February 2016 after being piloted in six counties (Kitui, Nyeri, Kwale, Samburu, Uasin Gishu and Kisumu) beginning August 2013. It was known as Teacher Performance and Integrity Programme in Kenya funded by Britain's DFID to the tune of Kshs 250 million. About 500 public primary 
and secondary schools have benefited (TSC Annual Report, 2014-15) from the program. The appraisal system enables the commission to identify the gaps facing teachers with challenges to improve. Various reports indicate that poor supervision in schools have led to teacher absenteeism and desertion, besides the low levels of numeracy and literacy among students and even teachers inability to understand the curriculum. Teachers and field officers have been sensitized on the performance Contract and Appraisal but there still exists challenges in the implementation which have to be addressed and as it is argued says, teacher appraisal process often faces problems associated with lack of agreement on appropriate appraisal criteria, concern over the validity and reliability of evaluation methods and the negative perceptions of teachers towards the appraisal system (Peterson, Cross, Johnson, \& Howell, 2000). The system has experienced several challenges namely:

- Understaffing. Lack of enough teachers has hampered the appraisal system as it's not possible to achieve targets with lack of enough manpower. Most teachers are overworked and therefore cannot deliver as expected.

- Targets. Setting of low targets.

- M\&E. This is still not being done as expected due to lack of transport, inaccessibility of some areas and officers being in charge of vast areas.

- Trade unionism. The teachers unions KNUT and KUPPET has persistently resists performance contracting for fear that many of their members would face numerous disciplinary actions. They have been however been assured by the Teacher Performance and Integrity Performance and Integrity Programme in Kenya that the appraisal system would focus on corrective support development of a teacher.

- Lack of computer Literacy. Despite the sensitization of teachers and field officers little has been done in respect to those who are not computer literate yet every teacher should fill his appraisal online then appraised online.

- Poor infrastructure. Some areas have no network forcing both the teachers and officers to go for long distances to appraise and be appraised.

The Commission has further allayed the fears of teachers by giving them facts about the performance contract and appraisals in the following ways as stated in the TPAD Manual (2016). 
Table 1.3: The Facts and Fallacy

\begin{tabular}{|l|l|}
\hline FALLACY & FACT \\
\hline $\begin{array}{l}\text { Performance contracts will change } \\
\text { terms and conditions of service for } \\
\text { teachers from permanent to } \\
\text { contractual. }\end{array}$ & $\begin{array}{l}\text { Terms and conditions of service for TSC } \\
\text { employees on permanent and pensionable terms } \\
\text { will not change. Performance contracting and } \\
\text { appraisals are ways for monitoring the } \\
\text { performance of teachers as stipulated in the TSC } \\
\text { Act.2012. }\end{array}$ \\
\hline $\begin{array}{l}\text { Performance Contracts are meant to } \\
\text { victimize. }\end{array}$ & $\begin{array}{l}\text { Performance Appraisal seek to improve } \\
\text { performance of schools and learning outcomes }\end{array}$ \\
\hline $\begin{array}{l}\text { Performance contracts will not } \\
\text { guarantee teacher promotions. }\end{array}$ & $\begin{array}{l}\text { Performance Contracting and appraisals will help } \\
\text { TSC in making key management decisions such as } \\
\text { assignment of teachers, deployment to } \\
\text { administrative positions, promotion and } \\
\text { appropriate training programmes. }\end{array}$ \\
\hline $\begin{array}{l}\text { Conditions set in the Performance } \\
\text { contract may not be attainable (e.g. } \\
\text { infrastructure improvement) }\end{array}$ & $\begin{array}{l}\text { The Performance contracts for head of Institution } \\
\text { are negotiated before signing and will thus take } \\
\text { into account other prevailing conditions. }\end{array}$ \\
\hline $\begin{array}{l}\text { Performance contracts are meant to } \\
\text { intimidate teachers. }\end{array}$ & $\begin{array}{l}\text { The process will identify individual performance } \\
\text { gaps of teachers and provide support for } \\
\text { professional development to address the identified } \\
\text { gaps. }\end{array}$ \\
\hline $\begin{array}{l}\text { The bontracts are being } \\
\text { implemented in a hurry without } \\
\text { consultations with stakeholders. }\end{array}$ & $\begin{array}{l}\text { This process has been successfully piloted for } \\
\text { three years in schools across the country. }\end{array}$ \\
\hline $\begin{array}{l}\text { This is a ploy by the TSC to diffuse } \\
\text { salary demands by the teachers. } \\
\text { higher mean scores will have an } \\
\text { advantage over smaller schools. }\end{array}$ & $\begin{array}{l}\text { Salary and other terms of conditions of service are } \\
\text { determined through negotiations and guidance of } \\
\text { the salaries and Remuneration Commission, and } \\
\text { not through the contracts and appraisals. }\end{array}$ \\
$\begin{array}{l}\text { Targets to be achieved are arrived at after taking } \\
\text { into account the broad teaching learning context } \\
\text { such as available resources, entry behavior of } \\
\text { learners, existing facilities and general teaching } \\
\text { and learning environment. }\end{array}$ \\
\hline
\end{tabular}

Source: Teacher Performance Appraisal and Development (TPAD) Manual, 2016

\section{PROFESSIONALIZING THE TEACHING SERVICE}

The commission recognizes that a teacher is an important community and opinion leader. The TSC Act 2012, section 23 (1) requires the commission to register all qualified teachers and that only registered teachers should be allowed to teach in both public and private schools in Kenya. The objective of teacher registration is to establish and maintain in the standards on professional qualifications and competencies within the teaching service by ensuring that all teachers comply with the teaching standards (TSC Annual report, 2014-2015). The teacher registration and certification process has undergone major reforms and teachers can now register online on the TSC website. 
Digitization process have also seen all teaching jobs and advertising for promotions done on the TSC website www.tsc.go.ke. The TSC Act also empowers the commission to exercise disciplinary control over any person registered as a teacher. This had not been provided for before and the teachers outside the TSC employment were not subjected to the provisions in the Code of Regulations for Teachers. Under the new mandate, the commission will exercise disciplinary control over teachers in private and other learning institutions, particularly in regard to Registration and Deregistration. Section 30(1) of the Act provides for de-registration of teachers who fail to comply with the professional standards. Offences that may lead to de-registration include but are not limited to; committing an offence against a learner, obtaining registration fraudulently and conviction of a criminal offence.

This process has however faced some challenges such as;

- The registration is done online yet some teachers are not computer literate. They are forced to use the cyber cafes for registration leading to lack of confidentiality.

- Some schools especially in the Arid and Semi-arid Land (ASAL) areas are have limited choice but forced to employ teachers who are not registered due to lack of registered teachers in the areas. In addition, the private schools have not enforced this rule and this makes such teachers to escape being punished when involved in disciplinary cases. Following the introduction of online teacher registration, 34 teachers were de-registered on account of various disciplinary offences (TSC, Manual, 2014-2015).

According to Digolo (2013), there is still a perception by some teachers that this should only apply to teachers in public schools thus a large number are still not registered. They do not have TSC payroll numbers. The TSC though has a legal provision to register teachers, lacks an appropriate legal mechanism to ensure that all persons involved in teaching are qualified. Subsequently, several issues/questions emerge like;

- Why are ECDE teachers, adult education teachers and teachers of alternative provision of basic education who are trained not registered by TSC?

- Why are most teachers who are qualified serving in private schools not registered?

- Why are some trained teachers employed by primary schools committees and Board of Managements not registered?

Solutions will only be found if the above questions are answered then the issue of employing unregistered teachers will have been addressed.

Investment in human capital is an important ingredient to the realization of the country's development goals. Quality human resources in the education 
sector is a key factor not only in terms of resources utilization in the sector is a key factor but also in the setting of standards.

\section{PROMOTION OF TEACHERS}

Promotion of teachers should be above board all the time. It should be based on criteria that all teachers are conversant of as part of their terms and conditions of service. The criteria should contain elements that are observable, measurable and concrete. The criteria should consist of what is relevant and seen as contribution to the area of specialization. The Commission promotes teachers based on the requirements of the various schemes of service which provide for promotion through Teacher Proficiency Course (TPC), interviews and common cadre establishments or upon attainment of higher qualifications (TSC, CORE, 2015). This is based on the approved establishment and the budgetary provision (TSC Annual Report, 2012-2013). The purpose of promotion is to recognize or reward effort with the aim of improving quality of teaching, aligning employees for succession management, encouraging employees for succession management, encouraging employees to pursue higher qualifications and motivating employees to perform better in their duties and responsibilities (TSC Annual Report,2014-2015).

Although the commission has over the years continued to promote teachers, there are still over 13,565 teachers who have served in the same position in excess of 15 years without promotion (TSC Annual Report, 20142015). There are still many teachers who are due for promotion to various grades but cannot be promoted due to limited vacancies in the establishment and budgetary constraints. This has led to low morale, poor quality teaching and indiscipline among some teachers. Towards this end, there is need to provide more funding to address stagnation as indicated in Table 1.4.

Table 1.4: Teachers who have served in one job group for more than five years by 2013

\begin{tabular}{|l|l|l|l|}
\hline S/No & Details & Job Group & Over 5yrs \\
\hline 1 & Chief Principal & R & 16 \\
\hline 2 & Senior Principal & $\mathrm{Q}$ & 11 \\
\hline 3 & Principal Teachers & $\mathrm{P}$ & 97 \\
\hline 4 & Principal Graduate Teacher II & $\mathrm{N}$ & 3,636 \\
\hline 5 & Senior Graduate Teacher & $\mathrm{M}$ & 7,454 \\
\hline 6 & Graduate Teacher I & $\mathrm{L}$ & 12,411 \\
\hline 7 & Graduate Teacher II Traduate Teacher/S1 & $\mathrm{K}$ & 456 \\
\hline 8 & $\begin{array}{l}\text { UT G } \\
\text { Diploma/ATS III }\end{array}$ & $\mathrm{H}$ & 133 \\
\hline 9 & UT Tech Teacher/ATS IV & $\mathrm{G}$ & 22,629 \\
\hline 10 & P1 & & 55,815 \\
\hline TOTAL & & $\mathbf{1 0 2 , 6 5 8}$ \\
\hline
\end{tabular}

Source: TSC Directorate of Human Resource Management and Development 
During the period (2014/2015), a total of 21,822 teachers were promoted to various grades but compared to the above figures, this is very minimal to compared to the population in question.

Table 1.5: Promotion of Teachers

\begin{tabular}{|c|c|c|c|c|}
\hline S/No & $\begin{array}{l}\text { GRADE(JOB } \\
\text { GROUP) }\end{array}$ & $\begin{array}{l}\text { NO.OF } \\
\text { TEACHERS } \\
\text { PROMOTED }\end{array}$ & & TOTAL \\
\hline & & PRIMARY & $\begin{array}{l}\text { POST } \\
\text { PRIMARY }\end{array}$ & \\
\hline 1 & M-N(Interview) & 666 & 3,679 & 4,345 \\
\hline 2 & L-M(Interview) & 510 & - & 510 \\
\hline 3 & $\begin{array}{ll}\text { K-L(Common } & \text { Cadre } \\
\text { establishment) } & \end{array}$ & & & 8,954 \\
\hline 4 & $\begin{array}{ll}\text { J-K(Common } & \text { Cadre } \\
\text { establishment) } & \end{array}$ & & & 3,679 \\
\hline 5 & $\begin{array}{l}\text { H-J(Teacher Proficiency } \\
\text { Course) }\end{array}$ & 1,851 & & 1,851 \\
\hline 6 & $\begin{array}{l}\text { G-H(Teacher } \\
\text { Proficiency } \\
\text { Course(TPC) }\end{array}$ & 2,483 & & 2,483 \\
\hline & TOTAL & & & 21,822 \\
\hline
\end{tabular}

Source: Human Resource Management Directorate

From the Table 1.5 figures it therefore it follows that promotion of teachers has been a big challenge to the Commission with some teachers serving in the same grade in excess of 20 years. Lack of promotion creates low morale and lack of motivation to work which compromises the quality of education. This is a sensitive area that can make the integrity of the commission questionable. It is an area which is likely to be contentious and TSC though having the mandate may have to collaborate with other stakeholders such as Council for Quality Assurance and Standards, the County Directors of Education (Ministry of Education), Kenya National Examinations Council and Kenya Private Schools Association among others. There is also the need for National Treasury to deliberately adjust budgetary estimates to expand the establishment.

\section{TEACHERS CONDUCT AND PERFORMANCE}

The objective of exercising disciplinary control over teachers is to enhance professionalism and integrity in the teaching service. This is achieved through enforcement of the Code of Regulations and the Code of conduct and Ethics for teachers and the Secretariat staff (TSC Annual Report, 2012-2013). The discipline function in TSC is conducted through established discipline panels comprising of TSC Commissioners and Secretariat staff (TSC COSE, 2015). 
A significant number of indiscipline cases arise out of ignorance of the rules and regulations governing the conduct of teachers and secretariat Staff. Indiscipline in the teaching service also manifests itself in different forms with the most common being desertion, absenteeism, negligence of duty and professional misconduct. In the 2012/13 period, 1027 cases. In the period 2007/2008, a total of 1,331 cases were presented for hearing which included 1,088 fresh interdiction, 120 cases brought forward from the previous year, 13 secretariat staff cases and 10 review cases which had been presented to Teachers Service Appeals Tribunal (TSAT). A total 1,286 cases were finalized out of this number which translates to $96.6 \%$ against a target of $97 \%$ (TSC Annual report 2007/2008). A total of 1187 cases which include 160 pending cases from the previous year were finalized (TSC Annual report, 2012-2013). During the period 2014/2015, the Commission Registered 983 discipline cases compared to 1,185 in the previous year. This reflects a decrease of 147 cases which is attributed to improved supervision through the TSC County Directors. In addition, 1,204 which include 221 pending cases from the previous year were finalized (TSC Annual report, 2015/2015).

Teacher discipline has also bedeviled with a number of challenges such as;

- Delays experienced in the determination of cases on financial malpractices presented without the mandatory final audited accounts by Ministry of Education for Secondary Schools and Annual Audit Report for primary Schools (TSC, Annual report, 2008/2009).

- Hostile and uncooperative witnesses (TSC, Annual report, 2008/2009)

- Defective interdictions by field agents and inadequate supporting evidence or delays in submission of the same contributed to delays in the dispensation of discipline cases increasing number of court cases instituted by teachers against disciplinary panel decisions posted a great challenge to the Commission (TSC Annual report,2014/15)

- Lack of technical capacity to investigate cases and interpret reports (TSC Annual report, 2012/2013) by the field officers.

- Failure by accused teachers and some witnesses to appear for the hearing (TSC Annual report, 2012/2013).

The Commission has employed a pro-active approach by creating awareness of the provisions among teachers to help them internalize the same. Teachers who violate the provisions are subjected to fair corrective measures to ensure justice for both teachers and the learners. It is worth noting that teachers found guilty of transgressing this provision against learners, presenting fake academic or professional certificates and those convicted of criminal offences are dismissed from service and removed from 
the Register of Teachers. The names are then published in the Kenya Gazette to guard against their re-engagement in any learning institution.

The Commission has taken several steps to ensure that a teacher is given fairing according to Regulation 145(6) in the Code of Regulations, (2015). The Investigating Panel shall, upon investigation process which shall include being:

- Presumed innocent until proven that she/he has a case to answer

- informed of the allegation, with sufficient details to answer it

- Given at least seven days to prepare a defense

- Given an opportunity to appear in person before the Investigation Panel, unless her/his conduct makes it impossible for the investigation to proceed in his presence;

- Given an opportunity to appear in person before the Investigation Panel, unless his conduct makes it impossible for the investigation to proceed in his presence.

- Present when the witnesses are being interviewed by the Investigating panel;

- Warned that any incriminating evidence may be used against her/him during the disciplinary proceedings; and

- Given an opportunity to adduce and challenge and challenge any adverse evidence.

- According to regulation 156(1) of the TSC Code of Regulations for Teachers, 2015, where a teacher is aggrieved by the decision of the Commission in a disciplinary process, the teacher may apply for review to the Teachers Service Committee within ninety days from the date of the letter communicating the decision.

Measures to address this transgression of the provisions to reduce the occurrence of indiscipline amongst teachers, an annual target of sensitizing heads of public educational institutions, field officers and the agents on teacher discipline was set. The purpose of the exercise was to educate the participants on the provisions of the Code of Regulations for Teachers and the Code of Conduct and Ethics (TSC Update, August, 2016).

\section{LITIGATION}

There has been a sharp rise in court cases instituted by teachers to challenge the Commission's decisions on discipline, transfers, and postings. Further, these matters also relate disputes arising from the general execution of the commissions mandates. Responding to queries on Nakuru Court case (1997) has become a major challenge (TSC Annual report, 2012/2013). A group of retired teachers from Nakuru who allege noncompliance on the part of the Commission/Government with a judgment which awarded salary 
arrears and pension dues in accordance with the Judgment (TSC Annual report, 2014/2015). Government has since appealed the judgment in the Supreme Court. In the event that the court process ends in the favor of the retired teachers, the financial and policy implications of court decision will be enormous and may be unsustainable in both the short and long term.

\section{INFORMATION, COMMUNICATION AND TECHNOLOGY INTERGRATION}

TSC witnessed tremendous growth in ICT capacity between 2012/2015, which has contributed to effective cost management and reduction in duplication of effort in performing different tasks. The aim was to increase efficiency in operations and to ensure services are available to the teacher and other stakeholders on the TSC website (www.tsc.go.ke) and teachers' portal (www.teachersonline.go.ke; TSC Annual report, 2012/2013,2015/2015). Teachers are now able to access pays slips, apply for registration, promotion online, appraise and be appraised online and keep track on the progress (TSC CORE, 2015).

TSC is committed to improving its automation level in compliance with e-government guidelines. During the period 2014/2015, the Commission made remarkable progress in realizing automation in its key teacher management functions. This had a significant improvement and positively impacted on service delivery. Teacher Management Information System (TMIS) was developed to enhance efficiency in the management of teachers' data through data capture and harvesting at source aimed at creating a repository. Although the Commission has made great progress in automating its processes as required by the standards of the directorate of eGovernment, there has been inadequate technical control for outsourced systems such as IPPD, IFMIS, thus causing frequent downtimes. Internal information systems are also separate and discrete which calls for their integration to place them on the same platform. Delay in digitization of records has also reduced efficiency in record management and hampered faster accessibility of files (TSC Annual report, 2015/2015).

There is need to increase the ICT budget to enable the Commission to achieve a higher level of automation to include a deliberate skill transfer program for internal technical capacity to effectively manage outsourced systems. A higher ICT budget is also needed for the development of a proper disaster recovery and business continuity plan, mitigating any data loss, integrating all information systems at TSC and proper digitalization of records to ease information retrieval for better service delivery and reduce cost on paper use. More teachers should be trained on ICT integration. So far 62,784 have been trained on ICT integration in primary education (TSC Annual report, 2015/2015). 


\section{MANAGEMENT OF HIV AND AIDS}

In several countries, the education sector has already been profoundly affected by HIV and AIDS pandemic. In several counties, the education sector has already been profoundly affected by the disease. It is estimated that the number of teacher deaths in Kenya tripled between 1995 and 1999, with HIV and AIDS thought to be the largest contributor to teacher mortality (Kelly, 2000). An analysis by the International Labour Organization on the impact of HIV and AIDS scourge on human capital suggests that Kenya was second only to South Africa in the sheer number of teachers dying from HIV infection by 2010, which is far ahead of Nigeria, Zimbabwe and Uganda (Cohen, 2002). Most school-based interventions in Sub-Saharan Africa rely on teachers as behavior formation and behavior change agents to deliver prevention messages to children. Few target teachers are the direct beneficiaries although teachers themselves are at risk of HIV infection. In a study, Mumah (2003) found that 36 percent of married respondents had sex with more than one partner in the year preceding the survey among primary school teachers in Rachuonyo District Nyanza province, Kenya.

The spread of HIV/AIDS have devastating effects on teachers in developing countries for some time now. The pandemic greatly reduces the capacity of the system by increasing teacher attrition and absenteeism (World Bank, 2005). It also saps the system's energy by imposing additional demands on teachers as they provide support for ill students and students with ailing family members. In some countries in Africa, the number of teachers lost due to HIV/AIDS each year has been close to half the number trained for each year (Nilson, 2003). According to a study done by Njeru and Kioko (2004) in Kenya, overall teacher death increased from 1,216 in 1997 to 2,133 in 2003 due to HIV/AIDS which is phenomenon. The number of counsellors at the TSC headquarters is not adequate to deal with HIV and AIDS related issues nationally. In addition there is need for counsellors to be deployed in district sub-Aids control units (ACUs) to enhance awareness but there is no budgetary allocation for the provision of counselors in these units. The commission is still grappling with stigma and discrimination of employees living with HIV and AIDS both at TSC headquarters and Institutional level.

Several groups in Kenya have taken an initiative to take action to address this gap. The Ministry of Education, Science and Technology has made HIV testing services available to teachers at its headquarters (Daily Nation, 2006). The Kenya National Union of Teachers (KNUT), in collaboration with the American Federation of Teachers (AFT), is implementing HIV workplace programs for teachers in selected regions (Davies \& Barimbui 2006). In addition, the Horizon program, in partnership with UNICEF, has begun an operations research project to test a model of 
HIV prevention and care activities directed at teachers in schools. Specifically, the Horizons study is assessing changes in teachers' knowledge of HIV and AIDS, risk behaviors (e.g. multiple partners and unprotected sex), and utilization of voluntary counseling and testing (VCT). The Horizon operations research project is already underway in 120 schools. Named "Teacher Matter", the project revolves around a self-directed workplace manual developed by UNICEF. Horizons has prepared a series of brochures and other behavior change education materials specifically for teachers that address various topics such as HIV prevention; management of STIs and HIV, including opportunistic infections, care and support, and condom use. Program staff have distributed copies of the workplace policy and trained peer educators in each school to reach fellow teachers. These outreach measures have created awareness in the teaching fraternity in the country specifically in primary and secondary school levels.

The program is addressing four major areas namely: prevention, HIV status awareness, stigma, care and support. About 37 out of the 111 training participants underwent testing for the first time. The intervention started in April 2006. More VCT services have been made available during peer educator sessions. The workplace model aims to assist teachers who are infected with and affected by the disease by helping them to identify and access available treatment, care and support community resources. This update summarizes the results of the baseline survey conducted in October, 2004.

\section{INDUSTRIAL UNREST}

Teachers form a vital part of the workforce in any progressing society and without their influence and input, there would not be a proper avenue for learning and knowledge advancement therefore. Teachers' strike has a way of paralyzing the society and disrupting learning with disastrous effects to the economy. The first teachers strike was in the year 1962 just before the country achieved independence. Subsequently over a period of time there have been a total of 11 teachers strike. The second strike was held on October 1962. The grievance was that the teachers union wanted one employer for all teachers in the country. However, this issue remained unresolved leading to the third strike on November 1966 leading to the formation of The Teachers Service Commission (TSC) through a bill which was tabled in parliament by the then Minister for Education, Jeremiah Nyaga. The fourth strike in November 1969 saw the formation of the Teachers Service Remuneration Committee (TSRC). In October 1997 demanding for a $300 \%$ pay rise. Led by the late veteran unionist Ambrose Adongo where teachers threatened to paralyze not only learning but also examination dates. Another strike was witnessed in October 1998, with the 
union blaming the government for refusing to implement the pay rise yet it they undertook implement the agreement through the president's committee. However on being promised, they went back to class only to strike again in October 2002 demanding their pay rise which they legally earned in 1997. The strike caused a major paralysis in the education system that lasted for two weeks.

The January 2009 strike was dubbed as the 'mother of all strikes' because almost 8million children were affected by the go-slow. The teachers wanted a sum of 19Billion to be paid but with a lot of persuasion by the government the teachers went back to school with a promise of pay 17.3Billion in phases citing hard economic times. In September 2011 teachers downed their tools yet again lamenting that they were inadequately staffed due to the influx of students/pupils due to the introduction of free primary education by the third president of Kenya, Mwai Kibaki's government. In July 2009 there was strike where the teachers demanded their $300 \%$ pay rise and responsibility allowance. The strike was held for 24 days and although it was ruled illegal by the Industrial court, the Teachers union leader, Wilson Sossion held his position and the teachers went on with the strike. The last strike was in September 2015 because the government did not honor Justice Nduma Nderi's 50-60 per cent pay. On October 3, 2015, the two teachers unions-Kenya National Union of Teachers (KNUT) and Kenya Union of Post Primary Education Teachers (KUPPET) asked their members to return to work bringing to an end a five week stoppage that paralyzed education.

The frequent disruption of teaching and learning in public educational institutions as a result of Industrial disputes related to teacher remuneration is a reality TSC must grapple with. To resolve this, a collective Bargaining Agreement (CBA) was signed on $25^{\text {th }}$ and $26^{\text {th }}$ October 2016 between TSC and the two teachers union. The CBA has established a new grading and salary structure based on the principle of "equal pay for equal work". This will now make it possible to retain the best professionals in public schools. It will witness the promotion of more teachers following the phasing out of the P1 entry grade in an agreement reached between the teachers' employer and their union representatives. The CBA agreement expands the grading structure of the top cadre of teachers. It has also created distinct career paths for all teachers in what is said to be a new paradigm shift in the remuneration of teachers meant to ensure that both the teachers in administrative and non-administrative positions have clear career progression paths.

This is the first ever Collective Bargaining Agreement (CBA) to be entered into by KNUT, KUPPET and TSC and negotiations have been going on since June 2016. It will bind the parties from 2017-2021. TSC Chief 
Executive Nancy Macharia said detailed and comprehensive implementation modalities and timelines will be worked out before the commencement of the CBA which takes effect from July, 2017. The signing of the CBA therefore marks the era of commitment by both parties to address labour issues and other matters of mutual concern for Industrial harmony in the sector, "she said (Wanzala \& Mwangi, 2016).

\section{DEPLOYMENT OF EFFECTIVE TEACHERS LEADERSHIP POSITIONS}

Globally, education reform focused on school improvement has been a key political agenda over the past few decades. Within the broad discourse, the preparation and development of school leaders has gained prominence primarily because of the perceived links between school leadership and school outcomes. Consequently, leadership preparation and development courses have been constructed as one of the major leverage points for policy makers and a topic of interest for scholars (Asuga, Eacot \& Scevak, 2015). Where there is an established, and continually expanding programme on school leadership preparation and development in developed nations especially the USA and Britain in developing nations, particularly those in Africa, we are seeing an increasing emerging voice in the discourses supporting the view that effective leadership and management are essential to developing good schools (GOK, 2008).

Leadership is a very critical component in any organization because it provides an enabling environment for processes to be actualized. In Kenya, school leadership preparation and development has been recognized through the provision of courses offered by universities, systematic authorities, professional associations and consultants. However, school leadership preparation and development has been criticized for being ad hoc, haphazard and not responsive to the needs of the current and aspiring school leaders (Onderi \& Croll, 2008; Wanzare \& Ward, 2000). Despite these claims what remain under researched is the current provision for school leaders and any form of evaluation thereof. Unlike the USA, England and Scotland who have a formal system of certifying, licensing and credentialing aspiring leaders, Kenya has adopted a modified version of the "apprentice model" (Sue et al, 2003). Principals are traditionally appointed from serving deputy principals or assistant teachers without any specific leadership preparation or development (Kitavi \& Van der Westtuizen, 1997). This method of selection has generated concerns on the basis that rapidly changing societal and education conditions requires the continuous development of staff to enable them acquire knowledge and skills necessary for their dynamic roles (Kindiki, 2009; Onderi \& Croll, 2008; Onguko et al, 2008). 
A pivotal reform initiative implemented by the Government of Kenya was the establishment of a national institute, the Kenya Education Management Institute (KEMI). It is mandated to provide educational leaders with competencies and bringing about paradigm shift among educational leaders and managers. However, a report on the Kenya Education Management Capacity Assessment (KEMACA, 2008) conducted by the Ministry of Education through funding from USAID. It reported that despite considerable financial resourcing, most principals feel that they have either not been prepared for their role or lacked key administrative skills even when they attended courses.

As a policy initiative, the Teachers Service Commission requires school administrators to attend a minimum of two development courses annually. The courses serve as a pre-requisite for recruitment or promotion to principal-ship. The TSC has already enacted regulations to ensure that teachers undertake career progression and continuous professional development programmes in line the market dynamics. This will ensure that all teachers including school managers such as principals, acquire the necessary skills in order to remain relevant in the respective positions. Towards this end, TSC is working with training institutions and capacity building agencies to develop modules to meet the requirements of section 35 of the Teachers Service Commission Act in compliance with teaching standards which states that the commission shall take all necessary steps to ensure that persons in the teaching service comply with the teaching standards prescribed by the Commission under this act (TSC Act, 2012). In his speech at the Kenya Secondary Schools Heads Association $38^{\text {th }}$ Conference at Wild Waters Mombasa ( $17^{\text {th }}$ June 2013-21 ${ }^{\text {st }}$ June, 2013), the Commission Chief Executive then Gabriel Lengoiboni said that the modules will be developed in a way to cater for the diverse career needs for different teachers. They will be organized in thematic areas such as the follows :

- School Management and Finance

- Curriculum Implementation and supervision

- ICT and Counselling

- Guidance and Counselling

The CEO then promised to review the policies on appointment of Heads of Institutions to make deployment to these positions performance based. This will ensure that only teachers with a proven record of good performance and the required training are appointed to positions of leadership. It is important to bear in mind those performance indicators such as the school's mean score, resource management, innovativeness and infrastructural development will play a key role in deployment decisions. The era of trial-and-error management style must come to an end. 


\subsection{CONCLUSION AND RECOMMENDATIONS}

Candid reports in teacher management calls for result based approach and cost-benefit analysis in every decision made. We therefore recommend that capacity building be embedded in teachers' programmes for effective teacher management to achieve the following:

1. Increase in productivity: Teachers will be at their best productivity if they have supervisors who will help them improve on their areas of weaknesses if constructive feedback is given. This therefore will help the TSC improve its productivity and reduce teacher disciplinary cases in return. Leadership training that encompasses emotional intelligence will enhance these emotional skills in people management and leadership roles. Leadership is about understanding your people's emotions which is critical to the success of any leader. Emotional intelligence involves being smart about emotions and using empathy effectively to empower and engage employees in their teaching duties.

2. Retention of teachers: Some teachers who voluntarily leave employment do so because of their superiors, they leave ineffective leaders hence by investing in leadership training, supervisors and managers will be able to retain teachers and reduce recruitment costs. This will be beneficial to TSC and the government at large.

3. Nurturing future leaders: TSC need to be strategic about developing and nurturing future leaders. Nurturing future leaders supports succession planning and offers career pathways to teachers, further increasing retention. This will be of great benefit to TSC at large.

4. Increasing teacher engagement: We all like to know how we are progressing in our roles, receiving praise when it is well-earned and constructive feedback as necessary. High percentage of highly engaged teachers receive feedback at least once a week compared to a few of those with low engagement. Giving feedback is a skill of successful leaders. Through leadership training, you will learn effective ways to give feedback to motivate and increase the skill level of the teachers.

5. Implementation an effective leadership style: Leadership training will assist in implementing the most appropriate leadership style for the commission and the roles the supervisors perform. Consistent capacity building will also help individual leaders develop their own personal leadership style that their team members will best respond to.

6. Better decision making: Leadership training will result in better decision-making because leaders functioning at a high level of emotional intelligence have the perspective to make informed, intelligent business decisions. This therefore, will ensure that your leadership training investment is returned. However the TSC secretariat must also be tagged along during 
these capacity building endeavors to help speak to the teachers' issues by use of best practice.

Bass (1990), submits that transformational leadership is characterized by several patterns of behavior. First, transformational leadership employs the charisma of leaders in order to gain the respect and trust of stakeholders and to instill pride in the latter. In addition, charisma highlights the provision of a common vision and sense of mission necessary for the transformation. The second distinction is inspiration through which leaders employ symbols to redirect followers' efforts; they express in a basic style the fundamental purpose of the transformation process, and clearly communicate the accompanying higher expectations. The third distinction is intellectual stimulation. Leaders intellectually stimulate employees by emphasizing rationality and creativity in problem-solving situations. Finally, transformational leadership offers individualized consideration where leaders treat employees individually offering them personal attention and, whenever necessary, they provide coaching and advise to those employees.

It is our informed opinion that, the supervisors will be able to understand the basics of sound management i.e. Clear objective setting, structured performance evaluation systems, honest and open feedback and communication with a human dimension. This will enable the commission to grow phenomenally and support the strategic objective as well as work towards the achievement of TSC mission to professionalize teaching service for quality education and development.

\section{References:}

Akala, J., \& Maithya, P. M. (2014). Effects of Teacher Recruitment and Utilization Policy on Quality of Secondary School Education in Kenya. IOSR Journal of Research \& Method in Education (IOSR-JRME) Vol.4(No.1 Ver.III), 10-17.

Asuga, G., Eacott, S., \& Scevak, J. (2015). School leadership preparation and development in Kenya: Evaluating performance impact and return on leadership development investment. . nternational Journal of Educational Management, 29(3), 355-367.

Cohen, D. (2002). Human capital and the HIV epidemic in sub-Saharan Africa. International Labour Organization.

Daily Nation. (2006, July 18). Be tested for HIV to know your status, Awori tells Kenyans. Daily Nation Newspaper.

Davies, J., \& Barimbui, L. (2006). Teachers helping teachers fight HIV/AIDS in Kenya. PEPFAR Implementers Annual Meeting.

Digolo, P. O. (2013). Teaching practice: Theory and Practice. Nairobi: KIE. Gabriel, L. (2013). The 38th National Conference Report of KESSHA Wild Waters. Mombasa. 
GOK. (2008). The Kenya Education Management Capacity Assesment (KEMACA). Nairobi: Government Press.

GOK. (2012). Sessional Paper No 14. Nairobi: Government Press.

GOK(Government of Kenya). (2007). Economic Survey . Nairobi: Government Press.

Hanson, D., Hitt, M. A., Ireland, R. D., \& Hoskisson, R. E. (2013). Strategic Management: Competitiveness and Globalisation. Cengage Learning Australia.

Hattie, J., \& Clinton, J. (2008). Identifying accomplished teachers: A validation study. Assessing teachers for professional certification. The first decade of the National Board for Professional Teaching Standards, 11, 313344.

Houghton, A. (2010, January 8). Performance reviews: Its about 'How' not 'Why'. United States of America: Business Week.

Hoxby, C. M., \& Leigh, A. (2004). Hoxby, Caroline M., and Andrew Leigh. "Pulled away or pushed out? Explaining the decline of teacher aptitude in the United States." The American Economic Review 94, no. 2 (2004): 236-. The American Economic Review 94, no. 2, 236-240.

Kindiki, J. N. (2009). Effectiveness of boards of governors in curriculum implementation in secondary schools in Kenya. Educational Research and Reviews 4.5, 260.

Kioko, U. M., \& Njeru, E. H. (2004). Funding the fight against HIV/AIDS: budgetary analysis of Kenya's HIV/AIDS activity: prioritization and financing. Nairobi: Institute of Policy Analysis and Research.

Kitavi, M. W., \& Van Der Westhuizen, P. C. (1997). Problems facing beginning principals in developing countries: a study of beginning principals in Kenya. . International Journal of Educational Development, 17(3), 251263.

Kotter, J. P. (1990). Force For Change: How Leadership DIffers from Managment. Free Press.

Ministry of Science Education \& Technology. (2005). Kenya Education Sector Support Programme: Delivering Quality Equitable Education and Training. Nairobi: MOEST.

MOEST. (2005). Sessional Paper No 1 on Policy Framework and Training. Nairobi: Government Press.

Mumah, S. J. (2003). HIV: Relationship between Knowledge, Attitudes and sexual Practices of primary school teachers in Rachuonyo District, Kenya. Unpublished M. ED Thesis. Nairobi, Nairobi, Kenya: Kenyatta University. Nilson, L. B. (2003). Teaching at its best. Bolton: MA: Anker.

Odhiambo, G. O. (2005). Teacher appraisal: the experiences of Kenyan secondary school teachers. Journal of Educational Administration, 43(4), 402-416. 
Onderi, H., \& Croll, P. (2008). In-service training needs in an African context: a study of headteacher and teacher perspectives in the Gucha District of Kenya. Journal of in-service education 34(3), 361-373.

Onguko, B., Abdalla, M., \& Webber, C. F. (2008). Mapping principal preparation in Kenya and Tanzania. Journal of Educational Administration, 46(6), 715-726.

Perraton, H. (2005). Open and distance learning in the Developing World. London: Routledge.

Peterson, K. M., Cross, L. F., Johnson, E. J., \& Howell, G. L. (2000). Diversity education for preservice teachers: Strategies and attitude outcomes. Action in Teacher Education, 22(2), 33-38.

Rivkin, S. G., Ertik, A., \& John, F. (2000). Teachers, Schools, and Academic Achievement, working paper. Massachusetts: National Bureau of Economic Research.

Santiago, P. (2002). Teacher Demand and Supply: Improving Teaching Quality and Addressing Teacher Shortages. OECD Education Working Papers, No. 1, 1-132.

Su, Z., Gamage, D., \& Mininberg, E. (2003). Professional preparation and development of school leaders in Australia and the USA. International Education Journal, 4(1), 42-59.

Teachers Service Commission. (2013). Annual Report 2012/2013. Nairobi: TSC.

Teachers Service Commission. (2014). TSC Act 2012 Revised Edition. Nairobi: National Council of Law Reporting.

Teachers Service Commission. (2015). Annual Report 2014/2015. Nairobi: TSC.

Teachers Service Commission. (2016). Teacher Perfomance Appraisal and Development Manual. Nairobi: TSC.

Teachers Service Management. (2002). Operation Manual on Teacher Management. Nairobi: TSC.

Tichy, N. M., \& Ulric 